Сања Ж. Ђуровић*

Универзитет у Крагујевцу

Филолошко-уметнички факултет

Катедра за српски језик

https://doi.org/10.18485/ai_petrovic_goran.2020.ch10

821.163.41.09 Петровић Г.

811.163.41'373.23

\title{
ТИПОВИ АНТРОПОНИМИЈСКИХ ЈЕДИНИЦА У КИНО-НОВЕЛИ „ИСПОД ТАВАНИЦЕ КОЈА СЕ ЉУСПА” ГОРАНА ПЕТРОВИТА
}

У раду се анализира стилска функција антропонима у зависности од њихове структуре, творбе и мотивације у роману Исйоg йаванице која се тьусйа Горана Петровића. Ономастичке јединице као део језичког система лишене су семантичког садржаја. Другим речима, оне само именују, не означавају. Међутим, у књижевном тексту оними имају више функција и њима се преносе различите поруке. Текст обилује антропонимијским јединицама и писац их је пажљиво бирао. Антропоними имају посебну функцију у тексту и стилски ефекат.

Кључне речи: Горан Петровић, Исйоg йаванице која се тьусй $a$, антропоними, ономастилистика

1. У раду се анализира стилска функција антропонима у зависности од њихове структуре, творбе и мотивације у кино-новели Исйоg йаванице која се љьсйа Горана Петровића. Ономастичке јединице као део језичког система лишене су семантичког садржаја. Другим речима, оне само именују, не означавају. Међутим, у књижевном тексту оними имају више функција и њима се преносе различите поруке.

* sdjurovic74@gmail.com; sanja.djurovic@filum.kg.ac.rs 
У литератури се као основни задатак стилистичке ономастике или ономастилистике истиче откривање начина на који ономастичке јединице - које су иначе семантички празне и имају функцију именовања - у књижевноуметничком тексту добијају конотацију и имају стилску функцију. Избором одређеног имена, презимена или надимка, аутор идентификује јунака. Циљ нашег рада јесте разоткривање стилематичности онимских јединица. „Под стилематичношћу се подразумијева онеобичајена језичка структура, а под стилогеношћу стилска вриједност онимске јединице” (Ковачевић 2012: 298).

2. „Таваница” је први пут објављена на руском језику под насловом „Киносеанс” 2005. године 1 . Имала је нешто више од седам страна. Прича је садржавала само опис догађаја, а „ликови су били неодређено именовани као група гледалаца..." (Петровић 2010: 180). У белешкама уз роман писац још каже: „Зато сам током 2005. и 2006. године, склапајући приповедачку збирку, решен да уврстим и причу „Испод таванице која се љуспа”, одлучио да персонализујем јунаке, њих тридесетак, који су филм гледали у тренутку када је пројекција прекинута, када је објављена смрт председника Социјалистичке Федеративне Републике Југославије" (Петровић 2010: 180). Након ових допуна Таваница је имала око седамдесет страна. Писац се причи поново вратио 2009. када је пожелео да учини неке измене и допише неколико страница, а дописао је око сто страница и књига је објављена на француском језику. Српска верзија у издању Новости из 2010. године има поднаслов кино-новела, а у односу на француско издање има и десетак страница више као и белешку писца где се истиче „како је свет приче независан и често сложенији у односу на наше животе, на животе писаца, читалаца и издавача" (Петровић 2010: 182).

1 Ове податке налазимо у белешкама уз роман које даје писац. 
Чињеница да је писац именовању јунака посветио посебну пажњу резултирала је тиме да сваки антропоним има своје место у роману и носи иза имена посебну причу. Ако је име и презиме обично, онда надимак преузима главну улогу.

У анализи се нећемо бавити примерима антономазије типа папагај Демократија пошто је о томе писао М. Ковачевић у раду „Двозначно (не)оглашавање Демократије у роману Горана Петровића Исйоg йаванице која се льсй $а$ " (2014). „Један од главних ликова романа јесте папагај чије је име Демократија. Будући да дата лексема има антономазијску функцију властитог имена, а као заједничка именица има значење врсте друштвеног уређења, бисемичност дате лексеме у тексту романа почива управо на интерференцији њеног основног и антономазијског значења" (Ковачевић 2014: 23) 2 .

3. Три главна јунака су Руди Прохаска, разводник Симоновић и папагај Демократија. Писац је тридесетак ликова сместио у краљевачки биоскоп у коме се, у једном тренутку, прекида пројекција на вест о Титовој смрти. У центру збивања је Чех Руди Прохаска чији је деда приказивао филмове и турском султану, а унук, који је наследио љубав према филму и оженио се Краљевчанком, остао је у Краљеву и основао биоскоп.

Критичари неретко говоре да су ликови воштани, умртвљени и заробљени у своје једнодимензионалне карактере базиране на наглашавању њихових хумористичких аспеката, или пак на критичком осврту ауторовом на ликове посматране као социолошке типове из времена о коме се приповеда. Нема продубљивања ликова, већ су то више скице лика. Кроз анализу имена покушаћемо да утврдимо зашто је то тако.

2 О значају поменутог и других ономастичких радова М. Ковачевића више у Шћепановић 2019. 
4. Анализа корпуса подразумева опис структуре, творбе и мотивације антропонима. Ради прегледније анализе корпус је представљен према структури. Запажа се да се у роману антропоними употребљавају самостално, као једночлане јединице (имена, презимена, надимци) и у различитим комбинацијама, као вишечлане јединице (двочлане: име + ирезиме, име + хийокорисииик имена, име + наgимак; трочлане: име + иррезиме + наgимак; име $+x и \bar{u} о к о р и с \bar{и} и к и м е н а ~+~ \overline{р е з и м е ~ и т д .) . ~ Т а к о ђ е, ~ и з д в а ј а ~}$ се група антропонимијских јединица која се односи на личности из уметничког живота. Често није могуће разликовати двочлано име, хипокористичку преинаку личног имена и надимак (нпр. Боgо, Мара и сл.), те презиме, породични надимак и надимак (Beঠu, Неваjga и сл.).

\section{1. Именовање мушких особа}

а) Пуно име и иррезиме (неїgе и среgне слово)

Јосип Гец (18); Ђурђе Ђорђевић $(48,113,118)$; Рудолф Прохаска (57); Франц Прохаска (57); Лазар Љ. Момировац $(74,108,118)$.

Поред нама уобичајеног Ђурђе Ђорђевић, јављају се и два чешка - Рудолф и Франц Прохаска. Страног порекла је и Јосип Гец. Презиме Момировац више личи на присвојни придев пошто се као презимена у листама презимена бележе само Момиров и Момировић, али и презимена на -ац су честа (нпр. Лутовац, Кањевац, Поломац и сл.).

аa) скраћено име и средње слово и презиме

Св. Р. Малишић $(9,19,22,150)$.

Писар Св. Р. Малишић - Малишић Држава - може се претпоставити да се намерно прави контраст мали(шић) 
према држава, могао се презивати и Великић. „Презиме је онако, звучи скромно, али надимак је моћан, да не може бити моћнији” (Петровић 2010: 9).

аб) надимак и презиме

Лаза Јовановић $(5,9,18,19,68,148) ;$ Руди Прохаска $(22,32,33,66,101,106,121,145)$.

Лаза је први лик са којим се сусрећемо у роману. Он је обућар пореклом из Рашке. Не зна да ли је Лаза надимак или право име, очекивано је да је надимак од Лазар. Главни јунак је Рудолф Руди Прохаска који је рођен у Дарувару где се његова породица доселила из Чешке. Осим биоскопа имао је жену Мару и папагаја Демократију.

\section{б) Само име}

Трајко (18); Коста (35); Драган (47, 108); Ибрахим (54, 110, 138, 154); Франц (61); Кемал (65); Крле (72); Његомир (78, 114); Марко (96, 149); Панта (102, 149); Јохан $(142,146)$.

Структура само име често се јавља у корпусу (око 11 пута) и разликујемо домаћа (Трајко, Коста, Драган, Његомир, Марко, Панта) и страна имена (Ибрахим, Франц, Кемал, Јохан). Панта је у вароши познат као Мајстор за ручак (Петровић 2010: 14), Ибрахим је посластичар, Његомир је рокер у одустајању, бубњар за свадбе, а Марко је кројач.

в) Само йрезиме

Симоновић $(30,39,83,120,123,151,152,170,171)$; Кра- 
сић (33); Јагодић (35); Аврамовић ${ }^{3}(41,118,124,156)$; Ђорђевић (48); Ераковић (50, 114, 133); Петронијевић $(80,111,161)$; Ресавац $(80,111,161) ;$; Санимировић $(80$, $111,161) ;$ Ускоковић $(83,86,164) ;$ Швабић (91); Прохаска $(104,151) ;$ Карајовић $(106) ;$ Момировац $(120,156)$.

Као и структура само име, тако и структура само презиме често се јавља у корпусу (око 14 пута). Петронијевић, Ресавац, Станимировић увек се јављају у роману заједно и овим редом - редом како седе у биоскопу. Уз Красића често иде атрибут бульави Красић (Петровић 2010: 33), што је поново контраст према презимену Красић од красан у значењу леп.

г) Наgимиз су веома стара антропонимијска категорија и најпогоднији су за креирање ликова. Најчешће су настали на основу физичког изгледа, карактерне особине, појединачне ситуације, хабитуалне радње, занимања, места, националности и сл. (уп. Ћирић-Ђурић 2017: 320). У литератури се издвајају неправи и прави надимци. Неправи су они који су настали варирањем елемената из имена или презимена, а прави су они који су мотивисани неким својством или појавом у вези са оним на кога се односи.

Чкиљац ${ }^{4}(34,149) ;$ Бодо $(44,108,113,115,126) ;$ Вејка $(46,113,118,129) ;$ Гаги $(47,108,113)$; Руди $(67,68)$; димничар Мушмула (68, 141, 150); Абрихтер (73); Невидљиви (20, 141, 148); Врежинац $(52,136)$; Кепа

3 Високи партијски функционер друг Аврамовић, који има грчеве у више од шездесет мишића руке због чега је неконтролисано подиже, као да нон-стоп гласа, а тај рефлекс представља ироничну метафору о бланко подршкама свакој одлуци КПЈ.

4 Чкиљац је кадровик, неумерено је пушио и због дима је стално капке држао притворене. 
(78); Ото (78, 118, 159); Чекањац $(83,115,165,166)$; Џиџан $(83,89,115,167)$; Фазан $(83,87,115,167)$; Цале (99); Ћоро (104, 141, 148); Милкинац (148); Крле (154, 156).

Физичке особине су често извор за метонимијско стварање надимака (нпр. Ћоро, Вејка, Чкиљац).

Чкиљац је добио надимак зато што је стално чкиљио, држао капке полуотвореним због дима од цигарета. Бодо (вероватно од Слободан) је градски пијанац. Мушмула је имао подвиг са пајањем таванице са које се откинуо као мушмула. Невидљиви је био доушник па отуда и такав надимак. Џиџан је турцизам који значи накићен, украшен и није случајно да такав надимак има онај који воли да се сређује и лепо облачи. Вејка је сува гранчица и није необично да има овај надимак јер је „био лаган као перце. Тешко да је имао педесет килограма... непрестано је био обузет паничним страхом да га ветар не одува" (Петровић 2010: 46).

Крле Абрихтер добио је надимак према упечатљивој ситуацији када је у биоскопу плашио друге да ће их абрихтером сећи. У литератури се овај тип надимака сврстава у оне чији си изворни домени њихове хабитуалне радње. Овакви надимци често имају замагљену мотивацију за оне који нису упућени у њихов настанак. Абрихтер је алатка за стругање и обраду дрвета, а Крле је погрешио и уместо циркулар рекао абрихтер. Нас писац уводи у контекст и разрешава мотивацију.

Врежинац је посредник и надимак је мотивисан тиме што врежа значи лоза и фигуративно значи да спаја, шири се и везује. Може се претпоставити да има ову мотивацију.

Већина надимака спада у праве надимке и једино се за Бодо према Слободан, Руди према Рудолф, Милкинац према Милка може рећи да су неправи. 
д) Трочлана структура: име и ӣрезиме и наgимак или име/ирезиме и наgимак

индустријалац Миљко Петровић Рижа (11); Миле Марковић Гроф (43); Селим Баку Аксу (64).

Малишић Држава (9); Миша „Шмол”(18); Крле Абрихтер (82, 108, 114, 139, 155,); Миле Гроф (43); Шваба Монтажа $(92,112,174)$; Божа Цугер $(94,148,150)$.

Само се три пута јавља структура пуно име и презиме и надимак, а чешће се јавља само име или презиме и надимак (шест пута). Миле Гроф је интерниста и добио је надимак гроф пошто је околина његово држање, манире и понашање оценила као грофовско.

ђ) само почетно слово имена

Ж. $(51,108,136) ; 3 .(51,108,136)$.

Потпуно необично, али стилски маркирано јесте именовање два лика само почетним словом имена - Ж. и 3. Није случајно што су баш Ж. и 3, а не нека друга слова. Седе у седмом реду и они су осми и девети лик које нам писац уводи, као што су Ж и 3 осмо и девето слово азбуке. Ништа код Петровића није случајно. Јављају се три пута и увек се о њима заједно говори. Они су градски мангупи од дванаест година и волели су да праве шале са Ераковићем који је седео испред њих. Можда и зато што су малолетни остају без пуног имена. Обојица су погинули као војници JHA у сукобима приликом распада Југославије од рикошета пушчаног зрна.

е) необични спојеви

капелан Вирт (18); Милкинац Бабл Гам $(29,81,119)$; Далипи Веби $(29,81,119)$. 
Милкинац Бабл Гам (bubble gum - жвакаћа гума) узвикује бабл гам док продаје жваке, кокице, он је повратник из Америке. Име Далипи Веби који је из Македоније делује веома експресивно, али нам је писац потврдио да се ради о стварном имену које је забележио (није га писац креирао $)^{5}$.

Укупно се у корпусу јавља око 50 мушких имена.

\section{2. Именоване женских особа}

За разлику од мушких имена, женски су у другом плану. Јавља се укупно четрнаест женских ликова и то се најчешће наводи само име (8 пута), само презиме (по оцу и по мужу) (2 пута), пуно име и презиме само једном у експресивном примеру Елоgија Неваjgа и три надимка.

а) Само име

Тилда ${ }^{6}$ (18); Јасмина $(54,138)$; Мара $(66,68,106,141$, $142,150)$; Христина $(83,87,115,167)$; Славица (91, 121, 123, 175); Деса (96); Каранфила (121); Герта (144, $145,146)$.

Овај тип именовања, само именом, најчешћи је код женских ликова. Поред Маре која је главни женски лик, супруга Рудија Прохаске, Славице, благајнице и Христине која је уз Фазана пар који седи у осамнаестом реду, остали женски ликови помињу се по једном и то успутно. Интересантно је име Тилда. Она је заносна певачица,

5 Мора се признати да услед изразите експресивности овог онима и овде смо имали идеје о скривеној мотивацији (*Да ли пиве би?), али нам је писац отклонио недоумице. Када се превише трага за скривеним трага се и тамо где га и нема.

6 Немачко порекло од Матилда. 
како писац каже „права фуфица”. Да ли је Тилда скраћено име од Матилда или Тилда или можда има везе са знаком за понављање речи ( ) (витичаста линија) остаје нејасно. Свакако је име необично и упечатљиво. Деса се може сматрати и надимком од Десанка. Каранфила је женско име настало према називу цвета, што је чест модел настанка онима. Она је фризерка. Герта је љубавница командира Гестапоа у Краљеву која је Рудију пред сам крај рата спасила живот.

\section{б) Само ӣрезиме (ӣо оиу и йо мужу)}

Ћирићева (83, 86, 89, 164); Ераковићка $(50,113,114)$.

Ћирићева и Ускоковић су љубавни пар. Њима писац помиње само презимена. Ћирићева је из угледне лекарске куће. Ераковићка је жена од Ераковића, уметника коме је неизмерно веровала.

\section{в) Нaguмaк}

Тршутка $(81,115,162,163)$; Цаца Капетанка $(83,87$, 89, 109, 115, 167); Мадам Пипи звана Сунцокрет (97, 116).

Тршутка је деведесетих променила име и презиме и сада има само надимак. Тршутка је била мушкарача, али је имала момке. Постала је познати модни креатор.

Цаца Капетанка је била професионално орјентисана ка војсци и била је љубоморна на Ћирићеву из лекарске куће. Њој је Џиџан био сводник и посредовао је између Цаце и „корисника”. То што је волела војнике, нарочито пешадинце донело јој је надимак Капетанка. 
„Неки су је звали по 'француски љупко' - Мадам Пипи. Неки други, грубо се шалећи - Сунцокрет. Јер није било муштерије која би доле зашла а да је она не би испратила погледом озареног лица." (Петровић 2010: 97). Није био довољан један надимак већ има два. Теткица у тоалету па отуди пи-пи.

\section{г) Име и иррезиме}

Елодија Невајда $(77,109,111,114,158)$.

Једини женски лик који има и име и презиме јесте наставница музичког. Иако постоји презиме Невајда (хрв.), очито је да је писац имао другачију мотивацију - да од ње нема вајде. Тако при крају романа писац каже: „Затим је у СУП-у поднела захтев за промену презимена. Одузела је оно 'Не' и постала Вајда Елодија" (Петровић 2010: 158).

Интересантно је и што име Елодија подсећа на Мелодија, а пошто је наставница музичког асоцијације су могуће и вероватно нису случајне.

5. Комични ефекти изазвани антропонимијским јединицама јесу имењаци, Роми Гаги и Драган. „Гагијево право име било је Драган, док је Драганов надимак био Гаги. Први, нешто старији Гаги, био је неписмен, па му је други увек читао шта то ситно пише на титлу, да, тамо, доле ..."(Петровић 2010: 47). Писац час каже старији Гаги и Драган, час млађи Гаги и Драган, па онда Гаги и Драган тако да се тешко може разумети ко је ко.

6. Заступљене су и антропонимијске јединице које се односе на познате личности. Ови ликови нису ликови романа, а они се током фабуле умећу да би се дочарао временско-социјални контекст и дала документарност. 
Крать Алексанgар Први Карађорђевић (13); Хајле Селасије (49,131); Марлена Дитирих, Чарли Чайлин, Гари Куйер, Грейа Гарбо, Ширли Темйл; Ханс Мозер, Пола Неіри, Руgолф Валеніично, Жан Габен, Аgолф Манжу, Луј Жуве, Емил Јаниніс, Хеgи Ламар (70); султан Абgулхамия Друіи (59, 63); Тахсин-йаща (60).

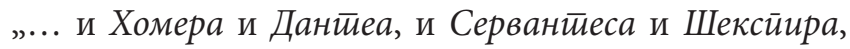
и Достиојевскоі и Мана...Посебно обративши пажњу на Раблеа и Гоїоља" (Петровић 2010: 132).

У роману се дају и натписи урезани на столицама међу којима су и антропоними: Теобил, Шоле, Слађана, Мирјана (27).

7. Може се закључити да од око седамдесет антропонимијских јединица скоро све су мотивисане и стилски маркиране. Након проведене анализе може се закључити да стилематични антропоними (номени и когномени) код Петровића представљају подлогу за изражену стилогеност.

На крају, када поставимо све ликове на своја места у биоскопу разрешава се Петровићев поступак у одабиру имена ликова. Од првог до последњег реда имена јунака нижу се почетним словима азбуке, од Аврамовића у првом реду, Бодо у другом, Вејка у трећем, Гаги и Драган у четвртом до Швабића - Швабе Монтаже који пушта филмове. Као да је писац прво сачинио овај азбучни попис ликова, а онда их надограђивао и уклапао те отуда можда и оправдање зашто нема продубљивања у грађењу ликова. Сваки јунак има своје тачно место и њих тридесет су поред три главна лика системски уклопљени у причу.

Ликови се постепено уводе како седе у биоскопу, од првог до осамнаестог реда, а на крају се даје епилог о главним ликовима шта је било са њима. Отвара се и затвара 
круг као на позорници, филму. Нема грађења ликова, већ се само дају основне информације о ликовима. Писцу није био циљ да продубљује психолошки профил ликова и шири слику, све је дато на нивоу скице лика.

Распоред имена ликова од првог до последњег реда у биоскопу има структуру акростиха (азбучни распоред слова од А до Ш) коју је немогуће лако уочити током читања. Издвајањем имена по распореду седења то се јасно уочава. У прилогу рада представљена је описана структура.

У духу постмодернизма ${ }^{7}$ да се систем и структура морају пореметити како би се оставило простора за варијације, за наставак, јер строга структура или систем значе завршетак и затварање круга, а нарушавање структуре оставља слободу и простор за даља промишљања оправдава Петровићево преметање редоследа у 18. реду па се прво уводи Џиџан, а затим Чекањац, као и намерно разбијање структуре у 8. реду где седи Врежинац. Иако је празнина за пролаз после 9. реда и било би логичније да се ту разбија структура, писац свесно структуру нарушава у реду испред. Све је код Петровића промишљено, јасно, а опет замагљено и остављено читаоцу да рашчитава и разуме на свој начин.

Све ово показује да су антропонимијске јединице у овом роману изузетно значајне. Галерија ликова и њихова стилематичност која је у раду анализирана у функцији је њихове стилогености како за сваки оним појединачно тако и у њиховој целости тако да би и стилогена анализа дала значајне резултате.

7 Више о томе у Л. Хачион 1996. 


\section{ИЗВОР}

Петровић 2010: Горан Петровић, Исйоg йаванице која се љусйа, Београд: Новости.

\section{ЛИТЕРАТУРА}

Ђуровић - Спасојевић 2017: Сања Ђуровић, Марина Спасојевић, „Стилска функција антропонимијских јединица у роману Време кокошки Добрила Ненадића", Зборник радова са 11. Међународног научног скупа на Филолошко-уметничком факултету у Крагујевцу (28-29. 10. 2016), књига 1: (Срйски) језик у комуникайивној функиији, уреgниии: М. Ковачевић, Ј. Петковић, Крагујевац: Филолошко-уметнички факултет, 179-188.

Јовић 1975: D. Jović, Lingvostilističke analize, Beograd: Društvo za srpskohrvatski jezik.

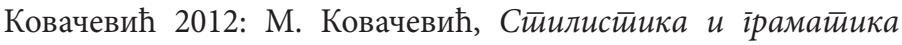
сиичлских фиіуура, Крагујевац: Кантакузин.

Ковачевић 2014: Милош Ковачевић, Двозначно (не)оіламаване Демокрайије у роману Горана Пеитровића „Исӣоg йаванище која се льусйа", у: Зборник радова са осмог међународног научног скупа одржаног на Филолошко-уметничком факултету у Крагујевцу, књига I: Вишезначности у језику, Крагујевац: ФИЛУМ, 23-34.

Ћирић-Ђурић 2017: Младен Ћирић, Љубица Ђурић, „Појмовни обрасци стварања надимака у српском језику”, у: Језищи и кулитуре у времену и ирросӣору, тематски зборник, Нови Сад: Филозофски факултет, 317-327.

Хачион 1996: Линда Хачион, Поейика йосиммоgернизма: историја, теорија фикција; превели: Владимир Гвозден, Љубица Станковић, Нови Сад: Светови.

Шћепановић 2019: Михаило Шћепановић, „Оними под лупом лингвостилистике”, Срйски језик XXIV, 127-134.

Прилог: Редослед седења ликова у биоскопу 


\begin{tabular}{|c|l|}
\hline I & Аврамовић \\
\hline II & Бодо \\
\hline III & Вејка \\
\hline IV & Гаги и Драган \\
\hline V & Ђурђе Ђорђевић \\
\hline VI & Ераковић \\
\hline VII & Ж. и 3. \\
\hline VIII & Врежинаи \\
\hline IX & Ибрахим и Јасмина \\
\hline \multicolumn{2}{|l|}{} \\
\hline X & Крле Абрихтер \\
\hline XI & Лазар Љ. Момировац \\
\hline XII & Невајда Елодија, Његомир \\
\hline XIII & Ото \\
\hline XIV & Петронијевић, Ресавац, Станимировић \\
\hline XV & Тршутка \\
\hline XVI & \\
\hline XVII & \\
\hline XIII & $\begin{array}{l}\text { Ћирићева и Ускоковић, Фазан и Христина, } \\
\text { Цаца Капетанка и Џиџан, Чекањац }\end{array}$ \\
\hline Швабић - Шваба Монтажа (кино-оператер) \\
\hline
\end{tabular}


Sanja Đurović

\section{TYPES OF ANTHROPONYMIC UNITS IN THE CINEMATIC NOVELLA „UNDER A CHIPPING CEILING” BY GORAN PETROVIC}

\section{Summary}

The paper analyzes the stylistic function of anthroponyms depending on their structure, formation and motivation in the novel Under a chipping ceiling by Goran Petrovic. Onomastic units as part of the linguistic system are devoid of semantic content. In other words, they just name it, they don't label it. However, in literary text, they have multiple functions and are transmitted different messages. The text is rich in anthroponymic units and the writer has carefully selected them. Anthroponyms have a special function in the text and a stylistic effect.

In the example of about 70 onims, its showed exceptional creativity and a clear structure that was established in advance.

Key words: Goran Petrovic, Under a chipping ceiling, Anthroponyms, Onomastylistics 